\title{
Reconstruction of the Model Recovery of Violence Against Women Victims Fairly Through the Development of Restorative Justice in the Globalization Era
}

\author{
Gayatri Dyah Suprobowati ${ }^{1}$, Hartiwiningsih ${ }^{2}$, Muhammad Rustamaji ${ }^{3}$ \\ ${ }^{1,2,3}$ Universitas Sebelas Maret \\ Surakarta, Indonesia \\ gayatridyah@staaf.uns.ac.id
}

\begin{abstract}
This research explains the new paradigm of law enforcement of sexual violence in the workplace that involves women as victims. This study shows how the psychological impact of sexual violence at work for women, as well as efforts that have been made to restore the psychological condition of victims. Based on the restorative justice approach, a criminal case that has a systemic impact on the victim, requires an ideal model of psychological recovery, so that the victim can return to its original condition. This process must be carried out because the victim has the right guaranteed by applicable law, to live and maintain a decent women .The victim has doubts, concerns and fears about reporting the incident, for the legal process that will be faced because of the ignorance of the victim in the procedure that should be taken.
\end{abstract}

Keywords-Violence, Victim, Women.

\section{INTRODUCTION}

According to the National Commission on Violence Against Women (Komnas Perempuan), violence against women is still at an all-time high in 2018. The total number of cases of violence reported was 406,178. Rape, sexual abuse, sexual exploitation, and marital rape are the most common forms of sexual violence. Even domestic violence against spouses is the leading cause of divorce requests in Religious Courts, accounting for around 392,610 cases. "Domestic violence is an ubiquitous and pernicious social problem that impacts millions of women each year," Rebecca L. Adams said in many of the identical cases around the world.[1]

The majority of efforts to safeguard women as victims are conducted in court. Victims' rights are frequently overlooked in judicial processes that rely on judges' choices. The court system is preoccupied with proving the prosecutor's charges against the accused, but it pays little heed to the victim's situation. "A criminal justice remedy is just not the best alternative for all victims," stated Kimberly D. Bailey, because the judiciary does not provide better access for victims of assault. "Forgotten folks, the invisible, a second class citizen, a second victimization, and double victimization" are terms used to describe such victim positions.[2]

The success of a judge's decision should be able to restore the victim's situation, both material and immaterial, in addition to being in compliance with the rules or processes. The judge's ruling just declared that the defendant was guilty and sentenced the criminal, but it made no mention of the victim's existence or fate. The interests of victims, which must be emphasized, can only be accomplished if the law against violence against women is renewed.[3]

In this era of globalization and rapid societal change, the debate over the use of restorative justice as a system to protect women as victims must be considered. This is to avoid "social disturbance and societal attention," as the law is accused of being outmoded and failing to uphold the rule of law. This arises as a result of "real enforcement" falling short of "total and complete enforcement." To put it another way, law enforcement is failing and many women victims are not receiving justice. [4]

Women who have been victims of violence frequently report to judicial institutions in order to seek justice. Because it breaches and violates the rights of victims, violence against women is illegal under the law. Even though the matter was resolved by a court judgment, the psychological impact on the victim will remain, necessitating a recovery process that is carried out on a regular basis and functions smoothly.[5]

Counseling can help in the recovery process. Counseling seeks to help people feel more secure, confident, and self-assured. Counseling can be done in this scenario not only face to face, but also indirectly through the use of technology (econseling). Victims can quickly communicate with 
their counselors through e-counseling. E-conseling is established as a concept that can promote women's equality in carrying out their activities after recovery with the implementation of gender-based.[6]

\section{RESEARCH METHOD}

The type of research the author uses is normative legal research that aims to find and describe the conceptual framework on positive law. This research is prescriptive using the statutory approach and conceptual approach. The data used are secondary data, namely primary legal materials and secondary legal materials which in general look at the phenomena that develop in society regarding violence against women, as well as how restorative justice can provide justice in the process of law enforcement. Data collection techniques were carried out with a literature study (document) which was further analyzed in syllogism.[7]

\section{FINDINGS AND DISCUSSION}

Violence should be able to be suppressed in a modern society founded on the values of rationalism, democracy, and humanism, yet violence is rapidly becoming a phenomena that leads to a systemic culture. Domestic violence is a severe social problem that is commonly underestimated, minimized, or disregarded because of misconceptions about who is at risk and from whom, according to Elizabeth L. MacDowell.[8]

The problem of violence against women is usually linked to a variety of topics, such as cultural concerns, religious interpretations, psychology, and gender relations, making it a very complicated subject. Even when women are the victims, the public is subconsciously implicated in pitting victims against each other. We could contribute to what Dianne Herman refers to as "rape culture."[9]

The victim's suffering or loss has been abstracted and compensated with the threat of criminal sanctions that can be inflicted on the offender in the formation of criminal law based on a retributive view. With this view, the state, whose legal standards have been broken by criminals, positions itself as a victim and so has the authority to demand and impose sanctions on the perpetrators through its law enforcement officers. The criminal justice system, on the other hand, is based solely on the application of the Criminal Code.[10]

In addressing situations of violence against women, the principle and philosophy of punishment, which is primarily geared towards the perpetrators and ignores the existence and interests of victims, indicates that criminal acts are regarded as confrontations between perpetrators and the state (no longer conflicts between perpetrators and victims).
The state, which has been formed and set forth under the rule of law, considers perpetrators to have breached the morality of life together. In this case, the victim's pain or loss is thought to have been embodied in a criminal consequence threatened by the perpetrator.[11]

During this time, the idea emerges that once a criminal has served his sentence, the victim's legal protection is seen to be complete. As a result, the victim's demands for compensation were deemed excessive. For women who have been victims of violence, this is deemed unjust. The definition of justice, which was previously founded on tradition and legal documents, must at the very least be altered by taking into account the victim's feelings and thoughts.[12]

Each country must pay attention to victims of crime by providing equitable services in the judicial process, according to the Nation Declaration of Basic Principles of Justice for Victims of Crime and Abuse of Power. However, because formal justice is difficult to achieve, restorative justice is an attempt to acquire justice through non-formal means. Not only is crime defined as a violation of abstract law against the state, but it is also defined as anything that is illegal for individuals and society. As a result, rather than focusing on the punishment of the criminal, it is considerably more vital to focus on the healing of emotional and material harm inflicted by crime.[9]

In order to respond to crucial facts, personal needs, and resolution in each situation, the measure of justice must be flexible. The accountability mechanism for perpetrators must be implemented by giving parties, such as victims, perpetrators, and the community, the opportunity to identify and determine their interests in relation to the consequences of crime, seek solutions aimed at healing, repairing, and reintegrating, and preventing future suffering.[13]

The consideration of the victim's interests in the resolution of the crime is not only related to the process of resolving the case, but also to the recovery of the victim's suffering, particularly with the provision of compensation, as stated in the 2002 ECOSOC resolution: "Restorative outcomes include responses and programs such as reparations, restitution, and community service, aimed at meeting the individual and collective needs and responsiblity of the victims."[2]

Various laws governing violence against women, such as Law No. 35 of 2014 concerning Child Protection and Law No. 23 of 2004 concerning Domestic Violence Elimination, have in principle incorporated the concept of restorative justice. This concept, however, does not apply to the accomplishment of illegal crimes by the use of criminal law or criminal law policy. While the 
Criminal Code and Criminal Procedure Code (Law No. 8 of 1981) have policies on violence against women, it appears that they do not reflect restorative justice. As a result, restorative justice must be recreated as a viable model for resolving genderbased violence.[14]

Restorative justice is a new approach to achieving justice for all. "Crime is a breach of people and connections," writes Zehr in (Van Ness \& Strong, 2015). It develops a sense of responsibility to make things right. The victim, the perpetrator, and the community are all involved in the quest for solutions that encourage repair, reconciliation, and reassurance. "States that restorative justice is" a process where all parties with a stake in a particular offense come together to deliberate jointly how to deal with the consequences of the offence and its implications for the future," according to Tony Marshall (in Braithwaite, 2002). The process starts with the recognition that the crime has caused harm. As a result, one of the goals of restorative justice is to heal the harm, to make things right.[14]

According to Roche (2004), "restorative justice is a process that brings together all stakeholders affected by the harm," and "restorative justice is a process that brings together all stakeholders affected by the injustice." That has been done... these stakeholders convene in a circle to discuss how the harm has affected them and to reach an agreement on what should be done to correct any wrongs that have occurred... Victims and perpetrators should, in theory, be participants. They are allowed some control over deciding how to respond to the harm caused by the offender's conduct. Restorative justice allows victims, offenders, and the community to participate in the creation of justice, giving them a voice and helping them to restore control over their life.[15]

Throughout much of human history, restorative justice has been the prevailing model of criminal justice for all people on the planet. Arrigo (Arrigo, 2014). Restorative justice theories can be found in both Western and non-Western traditions. According to Zehr (in Pavlich, 2005), non-judicial, non-legal dispute resolution approaches have reigned in the West for the majority of our history. People have generally been hesitant to involve the government, even when the government claimed a role. In reality, approaching the state and requesting that it proceed was fraught with stigma. For generations, the state played a minor role in criminal prosecution. Instead, it was thought that it was the responsibility of the community to resolve its own conflicts. The restorative justice paradigm is best understood as a return to the origins of justice, rather than as some new-age "cure-all" for a broken system.[16]
Restorative justice, according to Albert Eglash, is a meeting point between three different types of criminal justice: first, retributive justice, which focuses on punishing perpetrators for their actions; second, distributive justice, which focuses on rehabilitating criminals; and third, restorative justice, which is broad in scope. Eglash claims that The criminal justice system should take into account the negative repercussions of illegal acts by attempting to actively involve both victims and perpetrators in a process aimed at obtaining restitution for victims and rehabilitating violators.[17]

Between the criminal and the victim, the concept of restorative justice is different. The objective of holding restorative justice in instances with specified features exemplifies this distinction. Restorative justice is a system for restoring the victim's situation in major criminal instances, such as sexual violence, and it is directed to the victim's interests. Whereas in minor criminal acts, such as student brawls or acts involving children as perpetrators, the restorative justice mechanism is intended to ensure that perpetrators are not sentenced based on court sentences, but rather through mutual agreement between the perpetrator, the victim, and his family, with the goal of not only fulfilling the interests of the victims, but also avoiding the perpetrators being subjected to criminal sanctions.[18]

\section{IV.CONCLUSSION}

Restorative justice, for example, is founded on ethics, according to Furio, and is based on the concept that everyone deserves to be treated with more respect. This notion is utilized to propose remedies for soul healing, humanizing criminals, and/or providing alternatives to the punishment for the crime itself. This notion has evolved in the United States, as seen by the establishment of the Victim Offender Reconciliation Program at California State University in 1982, which aims to reconcile perpetrators and victims. With the introduction of The Community Justice Conference, which aims to provide an opportunity for perpetrators to "recover," that is, to restore themselves as normal members of society, such programs are becoming more common.

\section{REFERENCES}

[1] N. J. Santaularia, R. Larson, and C. Uggen, "Criminal punishment and violent injury in Minnesota," Inj. Epidemiol., vol. 8, no. 1, pp. 111, 2021.

[2] J. Goldstein, "Police Discretion Not to Invoke the Criminal Process: Low-Visibility Decisions in the Administration of Justice," Yale Law J., vol. 69, no. 4, p. 543, 1960.

[3] D. R. Jatmiko, Hartiwiningsih, and G. A. K. R. 
Handayani, "A political communication regulation model in local leaders election and legislative election for realizing a just political education," Int. J. Adv. Sci. Technol., vol. 28, no. 20, pp. 349-352, 2019.

[4] F. Nihayah, Hawtiwiningsih, and I. G. A. K. R. Handayani, "Politics of law enforcing death sentence based on the benefit of law," Int. J. Adv. Sci. Technol., vol. 28, no. 20, pp. 341-348, 2019.

[5] Z. O. Jainah and I. G. A. K. R. Handayani, "Religious terrorism," Int. J. Adv. Sci. Technol., vol. 28, no. 20, pp. 500-506, 2019.

[6] I. G. Ayu Ketut Rachmi Handayani, Pujiyono, and S. D. Sari, "Forensic and toxicological tests for protecting the patients of esthetic beauty clinic as the constitutional right in Indonesia," Indian J. Forensic Med. Toxicol., vol. 14, no. 2, pp. 2543-2547, 2020.

[7] L. Kajoko, Z. N. Rosidah, and I. G. A. K. R. Handayani, "Refleksi Paradigma Ilmu Pengetahuan Bagi Pembangunan Hukum Pengadaan Tanah," Bestuur, vol. 7, no. 1, pp. 114, 2019.

[8] T. Triwanto and E. Aryani, "The Urgency of Granting Authority to Assess Corruption Justice Collaborators," Bestuur, vol. 8, no. 1, p. 60, 2020.

[9] L. C. Lintang, Adriano Martufi, and J.W. Ouwerker, "The Alternative Concepts of Blasphemy Law in Indonesia: Legal Comparison with Ireland and Canada," Bestuur, vol. 8, no. 2, pp. 121-128, 2020.

[10] S. Gunawan, "The Principle of Control Non Primary Gun System of the Indonesian National Army Protect Soldiers," Bestuur, vol. 8, no. 2, p. $152,2020$.
[11] U. K. Mishra and A. Negi, "Transgender and the Right to Employment in India: Analysing the Trajectories of Discrimination," Bestuur, vol. 9, no. 1, pp. 34-43, 2021.

[12] S. Siddik, "The Origin of the Indonesian Blasphemy Law and its Implication towards Religious Freedom in Indonesia The Origin of the Indonesian Blasphemy Law and its Implication towards Religious," no. August, pp. 0-19, 2016.

[13] K. Henricks, "Power to the Paperwork? Mandatory Financial Sanctions and the Bureaucratic Means to Racially Unequal Ends," Am. Behav. Sci., vol. 65, no. 8, pp. 1104-1126, 2021.

[14] R. C. Sineath et al., "Determinants of and Barriers to Hormonal and Surgical Treatment Receipt among Transgender People," Transgender Heal., vol. 1, no. 1, pp. 129-136, 2016.

[15] J. Tallberg, "Paths to compliance: Enforcement, management, and the European Union," Int. Organ., vol. 56, no. 3, pp. 609-643, 2002.

[16] C. Minzner, "Judicial disciplinary systems for incorrectly decided cases: The imperial Chinese heritage lives on," Chinese Justice Civ. Disput. Resolut. Contemp. China, vol. 63, pp. 58-90, 2011.

[17] A. K. Jaelani and R. D. Luthviati, "The Crime Of Damage After the Constitutional Court's Decision Number 76 / PUU-XV / 2017," J. Hum. Rights, Cult. Leg. Syst., vol. 1, no. 1, pp. 31-41, 2021

[18] S. D. Baranyanan, "Simplification of Law Regulations in Copyright Criminal Act Settlement," J. Hum. Rights, Cult. Leg. Syst., vol. 1, no. 2, pp. 80-91, 2021. 